\title{
Пацієнт з інгібітором: особливості проведення хірургічних втручань
}

\author{
А.С. Кались \\ Державна установа «Інститут патології крові та трансфузійної медицини НАМН України», Львів, Україна
}

Сьогодні розвиток медицини дає можливість проводити хворим на гемофілію всі види операційних втручань та інвазивних процедур [1]. Обов'язковою вимогою для будь-якого хірургічного втручання у хворих на гемофілію $\epsilon$ замісна гемостатична терапія препаратами факторів згортання крові, спрямована на нормалізацію гемостазу та корекцію вторинних порушень гемостазу, спричинених травмою, запаленням та супутніми захворюваннями. Інгібіторна форма гемофілії (ІФГ) - одне з найтяжчих ускладнень замісної терапії при гемофілії, що характеризується утворенням інгібіторного антитіла до FVIII або FIX, яке не дозволяє проводити адекватної факторзамісної терапії. Будьяке операційне втручання у цих пацієнтів пов'язане з високим ризиком розвитку тяжких геморагічних ускладнень (як під час операції, так і в післяопераційний період), що потребує забезпечення надійного гемостазу і чіткого лабораторного контролю ефективності проведення гемостатичної терапії, що $\epsilon$ однією 3 найактуальніших проблем практичної гематології.

Наявні дані свідчать, що пацієнти з ІФГ не мають підвищеного ризику кровотеч, однак з їхніми кровотечами важче впоратися, що призводить до збільшення складності під час операційного втручання та підвищує ризик розвитку ускладнень [2-4]. 3 метою зменшення ускладнень необхідним $\epsilon$ проведення операційних втручань в умовах спеціалізованих центрів, які мають необхідний хірургічний, гематологічний, фізіотерапевтичний $\mathrm{i}$ лабораторний експертний досвід менеджменту пацієнтів із порушеннями гемостазу.

Відповідно до сучасних рекомендацій, пацієнтам з ІФГ операційні втручання або інвазивні процедури рекомендовано проводити під прикриттям препаратів із шунтуючим механізмом дії, таких як антиінгібіторний коагуляційний комплекс (аРСC) або рекомбінантний активований FVII (rFVIla). Ці препарати можна не застосовувати лише у пацієнтів, які отримують нефакторну профілактичну терапію, і лише у разі проведення малих маніпуляцій 3 мінімальним ризиком кровотечі (рисунок).

Рекомендації щодо менеджменту пацієнтів з ІФГ під час операційних втручань або інвазивних процедур:

- передопераційна оцінка повинна включати скринінг інгібітора до та після операційних втручань;

- операцію потрібно планувати на початку тижня і на початку дня для отримання оптимальної підтримки лабораторії i, якщо необхідно, станції переливання крові;
- медичний персонал, що здійснює догляд за пацієнтом із гемофілією, повинен мати досвід менеджменту пацієнтів із порушеннями гемостазу, зокрема хірурги-ортопеди повинні пройти спеціальне навчання (курси) для проведення хірургічного лікування хворих на гемофілію;

- хірургічні втручання та інвазивні процедури рекомендовано проводити під прикриттям препаратів із шунтуючим механізмом дії або еміцизумабом;

- у післяопераційний період рекомендовано здійснювати ретельний моніторинг стану пацієнта.

Дозування, інтервали дозування, тривалість лікування під час та після операції залежать від операційного втручання, загального стану пацієнта та клінічної ефективності в кожному конкретному випадку. У хворих на гемофілію всі операційні втручання поділяють на великі та малі, кожне з яких класифікують на три категорії: загальнохірургічні, ортопедичні та інші інвазивні втручання (табл. 1). Рекомендованим дозуванням для rFVIla $€ 120$ мкг/кг маси тіла, при малих операційних втручаннях - 90-120 мкг/кг. Мінімальна терапевтична доза для аРСС не повинна бути нижча $50 \mathrm{MO} /$ кг, оптимальна терапевтична доза -75 МО/кг. При цьому

Таблиця 1 Категорії хірургічних втручань [7]

\begin{tabular}{|c|c|c|c|}
\hline \multicolumn{4}{|c|}{ Поділ хірургічних втручань за категоріями } \\
\hline $\begin{array}{c}\text { Група } \\
\text { операційних } \\
\text { втручань }\end{array}$ & Загальна хірургія & $\begin{array}{c}\text { Ортопедична } \\
\text { хірургія }\end{array}$ & $\begin{array}{c}\text { Інші інвазивні } \\
\text { втручання }\end{array}$ \\
\hline Великі & $\begin{array}{l}\text { - Втручання на порожни- } \\
\text { нах тіла } \\
\text { • розчинення фасції } \\
\text { • видалення органа } \\
\text { - будь-яке операційне } \\
\text { втручання, не віднесене } \\
\text { до малих операційних } \\
\text { втручань }\end{array}$ & $\begin{array}{l}\text { - Остеотомія } \\
\text { - заміна суглоба } \\
\text { - синовіектомія } \\
\text { - остеосинтез } \\
\text { - ампутація } \\
\text { - артроскопія }\end{array}$ & $\begin{array}{l}\text { - Видалення >3 зубів } \\
\text { • видалення третього } \\
\text { моляра }\end{array}$ \\
\hline Малі & $\begin{array}{l}\text { Маніпуляції в межах: } \\
\text { • шкіри } \\
\text { • слизової оболонки } \\
\text { • поверхневої сполучної } \\
\text { тканини }\end{array}$ & $\begin{array}{l}\text { Хімічна-/ } \\
\text { радіоартроскопічна } \\
\text { синовіектомія }\end{array}$ & $\begin{array}{l}\text { - Венозний катетер } \\
\text { • видалення } \\
<3 \text { молярів } \\
\text { - ендоскопія без біопсії } \\
\text { - катаракта }\end{array}$ \\
\hline
\end{tabular}

Рисунок Рекомендації щодо терапії хворих хірургічного профілю з інгібіторами, які отримували еміцизумаб [5]

Невідкладна або планова операція чи інвазивна процедура у пацієнтів з інгібіторами, які отримували еміцизумаб

\begin{tabular}{|c|c|c|c|c|}
\hline \multicolumn{5}{|c|}{ Невідкладна або планова операція чи інвазивна процедура у пацієнтів з інгібіторами, які отримували еміцизумаб } \\
\hline \multicolumn{5}{|c|}{$\begin{array}{c}\text { Контакт з чентром лікування гемофілії } \\
\text { Інформація доступна у щоденнику лікування }\end{array}$} \\
\hline \multirow{2}{*}{\multicolumn{2}{|c|}{$\begin{array}{c}\text { Операція з незначним ризиком кровотечі } \\
\text { без додаткового фактора ризику }\end{array}$}} & \multicolumn{3}{|c|}{ Операція з ризиком великих кровотеч } \\
\hline & & \multicolumn{3}{|r|}{$\downarrow$} \\
\hline$\downarrow$ & $\begin{array}{c}\text { Стоматологічні } \\
\text { прочедури } \\
\downarrow\end{array}$ & \multicolumn{3}{|c|}{$\begin{array}{c}\text { rFVIIa } 90 \text { мкг/кг до та після операції } \\
\text { та кожні } 2 \text { год. + транексамова кислота }\end{array}$} \\
\hline \multirow{2}{*}{$\begin{array}{l}\text { Без додаткового } \\
\text { лікування }\end{array}$} & Транексамова & & & $\downarrow$ Відсутність ефективності rFVIIa \\
\hline & кислота & \multicolumn{3}{|c|}{ Відсутність ефективності rFVIla } \\
\hline \multicolumn{2}{|c|}{$\downarrow$ Аномальна кровотеча $\downarrow$} & $\downarrow$ Так & Якщо недостатня & $\downarrow \mathrm{Hi}$ \\
\hline \multirow{2}{*}{\multicolumn{2}{|c|}{$\begin{array}{c}\text { rFVIIa } 90 \text { мкг/кг більше ін'єкцій відповідно } \\
\text { до клінічної ситуації }\end{array}$}} & Людський & ефективність & \multirow{2}{*}{$\begin{array}{c}\text { аРСС початкова доза <50 МО/кг 20-25 МО/кг може бути } \\
\text { достатньою максимальною дозою } 100 \text { МО/кг/24 год }\end{array}$} \\
\hline & & FVIII & & \\
\hline
\end{tabular}


Таблиця 2 Рекомендоване дозування аPCC та rFVIIa для основних операцій у пацієнтів з ІФГ

\begin{tabular}{|c|c|c|}
\hline \multicolumn{3}{|c|}{ Рекомендоване дозування aPCC та rFVIIa } \\
\hline Препарат & Доопераційний & Післяопераційний \\
\hline rFVIla & $\begin{array}{l}\text { Болюсно } \\
90-120 \text { мкг/кг }\end{array}$ & $\begin{array}{l}90 \text { мкг/кг кожні } 2 \text { год перші } 48 \text { год, далі - } 90 \text { мкг/кг } \\
\text { кожні 3, } 4 \text { год, далі — } 6 \text { год на 3-тю, 5-ту та 8-му добу } \\
\text { відповідно, до повного одужання }\end{array}$ \\
\hline $\mathrm{aPCC}$ & $\begin{array}{l}\text { Болюсно } \\
75-100 \mathrm{M0/кг}\end{array}$ & $\begin{array}{l}70 \text { М0/кг кожні } 8 \text { год щонайменше } 3 \text { дні з максимальною } \\
\text { д0зою 200 М0/кг. Доза може бути знижена з 4-го дня } \\
\text { до } 50 \text { М0/кг кожні } 8 \text { або } 12 \text { год }\end{array}$ \\
\hline
\end{tabular}

на початку лікування аРСС рекомендовано призначати у дозі 20-25 МО/кг, далі - 50 МО/кг, максимально - $100 \mathrm{MO} /$ кг за 24 год (табл. 2) [6].

Таким чином, хірургічні втручання у пацієнтів з ІФГ необхідно виконувати під прикриттям замісної терапії препаратами із шунтуючим механізмом дії, такими як rFVIla та aPCC, які забезпечують надійний контроль кровотеч до, під час та після операційних втручань [8].

За підтримки ТОВ «Такеда Україна» VV-MEDMAT-37906

\section{Список використаної літератури/References:}

1. Rangarajan S., Austin S., Goddard N.J. et al. (2013) Consensus recommendations for the use of FEIBA $\left(^{(}\right)$in haemophilia A patients with inhibitors undergoing elective orthopaedic and non-orthopaedic surgery. Haemophilia, 19(2): 294-303. doi: 10.1111/hae.12028

2. Dunn A. (2015) The long and short of it: using the new factor products. Hematology Am. Soc. Hematol. Educ. Program, 2015: 26-32. doi: 10.1182/asheducation-2015.1.26

3. Srivastava A., Brewer A.K., Mauser-Bunschoten E.P. et al. (2013) Guidelines for the management of hemophilia. Haemophilia, 19(1): e1-e47.

4. Ju H.Y., Jang H.L., Park Y.S. (2015) The efficacy of bypassing agents in surgery of hemophilia patients with inhibitors. Blood Res., 50(3): 173-178. doi: 10.5045/br.2015.50.3.173

5. Srivastava A., Santagostino E., Dougall A. et al. (2020) WFH Guidelines for the Management of Hemophilia, $3^{\text {rd }}$ ed. Haemophilia, 26 Suppl 6: 1-158. doi: 10.1111/hae.14046

6. Susen S., Gruel Y., Godier A. et al. (2019) Management of bleeding and invasive procedures in haemophilia A patients with inhibitor treated with emicizumab (Hemlibra®): Proposals from the French network on inherited bleeding disorders (MHEMO), the French Reference Centre on Haemophilia, in collaboration with the French Working Group on Perioperative Haemostasis (GIHP). Haemophilia. https://doi.org/10.1111/hae.13817

7. Solimeno L.P., Escobar M.A., Krassova S., Seremetis S. (2018) Major and Minor Classifications for Surgery in People With Hemophilia: A Literature Review. Clin. Appl. Thromb. Hemost., 24(4): 549-559. doi: 10.1177/1076029617715117

8. Négrier C., Lienhart A., Numerof R. et al. (2013) SURgical interventions with FEIBA (SURF): international registry of surgery in haemophilia patients with inhibitory antibodies. Haemophilia, 19(3): e143-e50. doi: 10.1111/hae.12080

\section{Information about the author:}

Kalys Andrii S. - Head of the Surgical group for patients with hemophiliaos the SI «Institute of blood pathology and transfusion medicine of NAMS of Ukraine», Lviv, Ukraine

Address for correspondence:

Andrii Kalys

79000, Lviv, General Chuprynka str., 45

E-mail: kalysandriy@gmail.com

Надійшла до редакції/Received: 27.01.2021 Прийнято до друку/Accepted: 09.02.2021

\section{ТЕСТОВІ ЗАПИТАННЯ}

(один або декілька правильних варіантів відповідей на кожне запитання)

1. ІФГ характеризується:

$\square$ утворенням інгібіторного антитіла до факторів згортання крові

$\square$ утворенням інгібіторного антитіла до препаратів із шунтуючим механізмом дії

$\square$ утворенням інгібіторного антитіла до еміцизумабу

$\square$ усі відповіді правильні

2. Клінічна картина у пацієнтів з ІФГ характеризується:

$\square$ наявністю підвищеного ризику розвитку кровотеч

$\square$ відсутністю підвищеного ризику розвитку кровотеч

$\square$ хорошою відповіддю на введення концентратів факторів згортання

усі відповіді правильні

3. Пацієнтам з ІФГ операційні втручання

або інвазивні процедури рекомендовано проводити

під прикриттям:
$\square$ aPCC
$\square$ VII
$\square$ rFVIIa
$\square$ усі відповіді правильні

4. Коли показано проводити скринінг інгібітора у пацієнтів з ІФГ?
$\square$ до та після операційних втручань
$\square$ якщо клінічна чи лабораторна відповідь на застосування концентрату нижча оптимальної
$\square$ до та після заміни препарату
$\square$ усі відповіді правильні

5. Визначте рекомендоване дозування для rFVIIa на доопераційному етапі:
$\square$ болюсно 90-120 мкг/кг
$\square$ болюсно $80 \mathrm{мкг/кг}$
$\square$ болюсно 10-50 мкг/кг

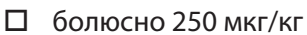

6. Визначте рекомендоване дозування для аРСС на післяопераційному етапі:
$90 \mathrm{MO} /$ кг кожні 2 год
ㄱ $70 \mathrm{MO} /$ кг кожні 8 год
$90 \mathrm{MO} /$ кг кожні 4 год
$\square$ усі відповіді правильні

7. Визначте максимальну добову дозу аРСС:
$200 \mathrm{MO} / \mathrm{kг}$
$\square \quad 400 \mathrm{MO} / \mathrm{kг}$
口 $120 \mathrm{MO} / \mathrm{kr}$
$50 \mathrm{MO} / \mathrm{kr}$

8. Визначте мінімальну терапевтичну дозу аРСС:
$\square 70 \mathrm{MO} / \mathrm{kr}$
$\square 50 \mathrm{MO} / \mathrm{kr}$
$\square \quad 100 \mathrm{MO} / \mathrm{kr}$
$\square \quad 120 \mathrm{MO} / \mathrm{k} \Gamma$ 